\title{
Genetic intervention and the parent-child relationship
}

\author{
TERRANCE MCCONNELL ${ }^{1}$
}

There is a long history of opposition to allowing parents to use biotechnology in order to select the traits of their children. Jurgen Habermas's book, The Future of Human Nature, is an important addition to this literature. Habermas, like C.S. Lewis and Paul Ramsey before him, is concerned that children's futures are fixed by parental choices and that genetic selection or modification treats children as objects rather than persons. This essay aims to show both why these objections resonate with many and why they nevertheless fail to provide good reasons to prohibit deliberate selection in general, and genetic enhancement in particular.

\section{Introduction}

Genetic enhancement seeks to use our knowledge of biology to create offspring with traits that the designers regard as improvements. John Harris puts it more forcefully: "In terms of human functioning, an enhancement is by definition an improvement on what went before. If it wasn't good for you, it wouldn't be enhancement."2 Methods of enhancement include modification and selection. ${ }^{3}$ Modification involves genetically altering an embryo for the purpose of producing desirable traits. Selection involves using in vitro fertilisation (IVF) and preimplantation genetic diagnosis (PGD) and transferring to a woman only those fertilised eggs that have the traits sought by the parents. Physical traits that might be sought include increased height and greater muscle tone. Cognitive enhancement might include greater memory capacity. Perfect pitch and various behavioral traits are also among the characteristics that some say prospective parents will seek. Possibilities will be limited to those traits that have a genetic basis. If the trait is determined by a single identifiable gene that is fully penetrant, then those using selection can be confident of the outcome (assuming the reliability of genetic tests). But many genes merely predispose individuals to have the relevant traits, and with widely varying degrees of probability. So here all that prospective parents can do is increase the odds that their child will have the traits they desire. Traits influenced by multiple genes will be even more difficult to select for or to modify, as will characteristics that are multifactorial. It is worth remembering that many of the traits that prospective parents are likely to want in their offspring - such as increased height and greater intelligence - are probably multifactorial.

The literature advancing objections to human enhancement is already vast. A common criticism is that pursuit of genetic enhancement poses a threat to human nature. ${ }^{4}$ Another objection is that a society that allows its members to use biotechnology to select the traits of their children will undermine some important values, including humility and solidarity, and will make parental responsibility overly burdensome. ${ }^{5}$ Others argue that enhancement is contrary to the goals of medicine, that it will exacerbate the gap between the "haves" and the "have nots", and that it will create an irrational "arms race" in pursuit of so-called positional goods (goods that enable one to get ahead only if others lack them).

Here I will focus on a different set of objections, ones centered on the idea that if parents are permitted to use selection or modification in the hope of having better children, this will have a negative impact on the parent-child relationship. This could occur in multiple ways. There

Genomics, Society and Policy, Vol.6, No.3 (2010/11) ISSN: 1746-5354

(C) ESRC Genomics Network. 
could be an adverse effect on either the created or the creators. One of the principal claims examined here is that the lives of children created by designing parents will be significantly less satisfactory than the lives of children created in the conventional way. This objection has a long lineage, tracing back to when the discipline of modern bioethics was in its infancy; Paul Ramsey was among the first to develop this line of criticism. ${ }^{6}$ It has been elaborated more recently by Jurgen Habermas.

\section{Enhancement}

First, we need to say something about the notion of enhancement. Stephen Wilkinson has distinguished two senses of this term - the "non-disease-avoidance" account and the "supernormality" account. ${ }^{7}$ The former, though an awkward label, applies when selection (or modification) is employed to produce an improvement by choosing a trait the absence of which would not constitute having a disease. Clearly, giving an account of what constitutes a disease is extremely difficult, and without such an account the non-disease-avoidance notion cannot tell us whether any given use of selection is one of enhancement. It is equally difficult to say what is meant by improvement. An example that is presumably not an instance of attempting to avoid a disease, on any plausible version of that concept, is the proverbial case of selecting for eye color; but such a case would constitute an improvement only if one had certain aesthetic preferences. The frequently used example of opting for greater intelligence is more likely to be accepted by many as being both an improvement and not avoidance of disease.

According to the super-normality account, prospective parents are pursuing enhancement if they are trying to produce offspring some of whose traits are improved beyond the normal range for humans. The case of choosing for intelligence will qualify here if the intelligence is beyond the normal range for humans.

The accounts will differ on some cases. If parents are selecting against low (but not pathologically low) intelligence, this will count as enhancement on the non-diseaseavoidance account because the prospective parents prefer the fertilised eggs that will become individuals who have greater intelligence, even though the other candidates are not diseased. But this will not be a case of enhancement on the super-normality account. On the other hand, if selection is made in favor of an exceptionally effective immune system, this will not be a case of enhancement on the non-disease-avoidance view, but will according to the supernormality account. ${ }^{8}$

It is not necessary here to choose between these accounts (or to develop a third one). For the most part, according to the objections that I am examining here, the key features of the practices being criticised are that traits are selected deliberately and are regarded by prospective parents as improvements. Indeed, the term 'enhancement' may be inapt. When using PGD, parents are choosing from fertilised eggs produced with their own gametes. So if they had conceived in the usual way, it is possible, though unlikely, that that same fertilised egg would have been produced. As the medical geneticist in Andrew Niccol's film Gattaca (1997) said to the parents of Vincent and Anton when they were creating the latter, "Keep in mind, this child is still you, simply the best of you. You could conceive naturally a thousand times and never get such a result." Whether we should call this enhancement is not clear to me. 


\section{Deliberate choice itself is the problem}

Some of the early opponents of "genetic engineering" believe that any deliberate choice of traits is wrong, and for multiple reasons (one of which is that it is apt to damage the relationship between parents and their offspring). Examining these very early critics of biotechnology reveals two interesting things: the quaintness (from today's perspective) of their targets and the striking similarity between their concerns and those of the more recent critics.

Even before Paul Ramsey, C.S. Lewis, in The Abolition of Man, expresses concerns over what he calls "Man's conquest." " His target, quite quaint by our standards, is "the contraceptive" or "contraception used as a means of selective breeding." ${ }^{10}$ His worry is that this sort of intervention in the core makeup of humans transforms them into something else, objects rather than persons. "The real objection is that if man chooses to treat himself as raw material, raw material he will be." 11 Lewis's diagnosis of the problem points to the presuppositions of those who would conquer all of nature: they view everything as up for grabs, including duty itself; they reject all limits and constraints. For this reason, they are not men at all. "Good' and 'bad', applied to them, are words without content." 12 Lewis's overall argument seems to be that value depends on some absolutes, and that one absolute is that one shall not tamper with human nature (or treat humans as mere objects). Failure to acknowledge this limit is taken to mean that one recognises no limits.

More than 25 years later, Ramsey echoes Lewis's concerns, attacking the "dehumanizing tendencies of technology." ${ }^{\prime 13}$ Ramsey's quaint initial target is artificial insemination by donor (AID), which he twice characterises as "the first breach" of "human parenthood." 14 But he does see a much bigger picture when he characterises his opponents as seeking "the control of the future of man through genetic manipulation and the alteration of human parenthood." 15 Both the artificiality of the means and the intent of the manipulators are viewed as problematic. "When the transmission of life has been debiologized, human parenthood as a created covenant of life is placed under massive assault." ${ }^{16}$ Like Lewis, Ramsey thinks that the interveners recognize no limits. "But the sine qua non of any morality at all, of any future for humanism, must be the premise that there may be a number of things that we can do that ought not to be done." ${ }^{17}$ Ramsey characterises "schemes for the improving self-modification of man" as "suicide of the species" suggestion, then, is that creatures created in this way will have lives that are less satisfactory than 'normal' humans, and this bad outcome can be avoided only by resistance now.

\section{Origins, identity, and self-understanding}

Habermas develops this line of reasoning further in The Future of Human Nature. His overall argument is that allowing parents to have control over the genetic makeup of their child will cause two significant problems for the beings that are created: they will have a sense of selfunderstanding that is detrimental to their well-being [the "self-understanding argument"], and they will have beliefs about how others (in particular, their parents) see them and how they are related to others that are contrary to their best interests [the "relationship argument"]. ${ }^{19}$ The first of these arguments will be explored in this section. 
When biotechnology gives parents the power to shape the genetic makeup of their children, Habermas thinks that "the categories of what is manufactured and what has come to be by nature" will have been merged. Putting it another way, he says that this leads to "blurring the intuitive distinction between the grown and the made..." ${ }^{20}$ But so what, we might ask? Does this really matter? Habermas acknowledges that "the question is how parents' rights to make eugenic decisions will affect their genetically programmed children, and whether the consequences of these decisions infringe upon the objectively protected well-being of the future child." ${ }^{21}$ This is to concede, in effect, that society should defer to parental wishes unless the welfare of their children is adversely affected by their decisions. So how is a child's welfare diminished if parents are permitted to make what Habermas calls "eugenic decisions"?

The key to Habermas's argument is his claim that there is a "connection between the contingency of a life's beginning that is not at our disposal and the freedom to give one's life an ethical shape." 22 The phrase 'at our disposal' does not mean at the individual's own disposal. Instead, it means under the control of any other human. To view oneself as morally free is to see one's origins as contingent, namely, not deliberately determined by other humans. An extensive quote from The Future of Human Nature makes this point.

We experience our own freedom wi th reference to som ething which, by its very nature, is not at our disposal. The person, irrespective of her finiteness, knows herself to be the irreducible origin of her own actions and aspirations. But in order to know this, is it for this person to be able to ascribe her own origin to a beginning which eludes hum an disposal, to a beginning that is, which is sure not to prejudge her freedom only if it $m$ ay be seen as something - like God or nature - that is not at the disposal of som e other person? Birth as well, being a natural fact, meets the conceptual requirement of constituting a beginning we cannot control. ${ }^{23}$

People can view themselves as free and responsible beings only if their character - who they are - was not deliberately determined by some other human. As Habermas puts it strongly, "The fact that this natural fate .... is not at our human disposal seems to be essential for our awareness of freedom." ${ }^{24}$ Deliberate intervention is bad because it negatively impacts selfunderstanding. "It is for this 'capacity of being oneself' that the 'intention of another person' intruding upon our life history through the genetic program might primarily turn out to be disruptive." ${ }^{25}$ Without a contingent beginning not at any human's disposal, an individual "could not perceive himself as the initiator of his actions and aspirations.", 26

If such self-perception is bad for a person, there seems to be an obvious solution: engage in benevolent deception and hide his origins from him. There are, however, two problems with this. First, such a strategy is impractical because it is likely to fail; and second, as Habermas correctly notes, the strategy also "raises the moral question of whether it is permissible to withhold from someone the knowledge of a biographically significant fact." 27 But this merely creates another problem. It now seems that the alleged loss of freedom and loss of capacity to initiate one's own actions are difficulties only if one assumes the truth of genetic determinism, a view discounted by most. Habermas resists this, however, when he says, "To associate this intuition with genetic determinism would be to misconstrue it." ${ }^{28}$ Habermas says that it does not matter how far genetic programming goes "in fixing properties, dispositions, and skills," nor does it matter how far it goes "in determining the behavior of the 
future person." 29 The point instead is how the person herself sees this. "The change would take place in the mind. Awareness would shift, as a consequence of this change of perspective, from the performative attitude of a first person living her own life to the observer perspective which governed the intervention one's own body was subjected to before birth." ${ }^{30}$ It now seems, however, that Habermas is assigning to the beings created a belief in genetic determinism. And if this is the source of the alleged problem, there are two obvious solutions. First, if genetic determinism is false, so instruct the beings created so that their misperceptions are corrected. But a second solution shows that the issue of genetic determinism is irrelevant. Let q, r, s, and t represent an individual's genetic components. Whether an individual was created the usual way or a part of his genetic makeup was selected by his parents makes no difference to his freedom. Either way, he has instances of q, r, s, and $t$, and in each case they play the same role (whatever that might be) in influencing his behavior. To the beings so created, we can say, "You are no more limited than anyone else."

I think that an honest reading of The Future of Human Nature reveals a tension between denying a commitment to the truth of genetic determinism (on the one hand) and seeing the problem as unfixable once parents choose the genetic constitution of their children (on the other hand). The latter perspective is driven home by Habermas's frequent use of the phrase "genetically programmed persons." It is reinforced when he writes about "the irrevocability of choices that proved decisive in setting the course of the life history of another person." ${ }^{\text {" If }}$ parental choices are "decisive" in setting the life histories of their children, it is hard to see how that is not an endorsement of genetic determinism, or at least a claim that genetically engineered children will believe such a view. Adding to this perception, Habermas says, "Eugenic interventions aiming at enhancement reduce ethical freedom insofar as they tie down the person concerned .... barring him from the spontaneous self-perception of being the undivided author of his own life." 32

One other point is relevant here. Habermas several times ${ }^{33}$ notes that defenders of genetic enhancement point out that parents also employ education and other environmental devices to influence their children's behavior and choices. Employing such environmental means to create advantages for children may be objectionable if, for example, they exacerbate inequalities. But they do not seem objectionable merely because parents are trying to influence their children's traits. Habermas recognises this and his response is to suggest that there is a substantial difference between environmental influences and genetic ones. He indicates that the latter are "unchallengeable" and the former are "essentially contestable". 34

The importance that Habermas attributes to this asymmetry, however, is problematic. From the agent's perspective, both environmental and genetic factors are external (beyond his control). But it is not obvious that one of these is more potent than the other. As Janet Radcliffe Richards has argued, some genetically based traits may be alterable (through somatic cell therapy, for example) and "some environmentally caused characteristics are quite impossible to undo." "35 Even outsiders may see environmental factors as limiting. John Stuart Mill, in his Autobiography, recounts how some of his associates seemed to discredit him: "He [John Sterling] told me how he and others had looked upon me (from hearsay information) as a 'made' or manufactured man, having had a certain impress of opinion stamped on me which I could only reproduce... "36 Mill expresses no bitterness about this, and goes on to say that his associates' opinions were changed when they saw how he held his own in discussions of Wordsworth and Byron. 
Habermas's language here suggests that he sees the self-understanding problem as unfixable because of the way that he (or the created child) understands genetic causation. But since an individual's metaphysical status is no different whether his genes are the result of the normal lottery or parental choice, the "self-understanding" argument cannot be salvaged. This may be put aside, however; for as Habermas's reasoning develops, the "self-understanding" argument dovetails into the "relationship" argument. From the perspective of the created beings, it is the "fixed intention of a third person" ${ }^{37}$ that is problematic. Even if the child created is a free agent, he is his parents' free agent. The intentions carry with them an attitude. If children are to see themselves as free, "practices of enhancing eugenics cannot be 'normalized' in a legitimate way, because the selection of desirable dispositions cannot be $a$ priori dissociated from the prejudgment of specific life-projects." 38 Traits that parents have chosen have been judged by them to be desirable. And this "commits the person concerned to a specific life-project or, in any case, puts specific restrictions on his freedom to choose a life of his own." 39 Even if the child is not genetically restricted, she is "confronted with the expectations of ambitious parents" to make use of the "mathematical or musical talents" (for example) with which they endowed her. The child inevitably sees these talents not merely "as an opportunity" but also as "an obligation." That which resulted from the natural lottery is an opportunity; that which was deliberately created is a burden. The problem, then, is not that others will know what she will become; rather, she has been manufactured, and with that comes burdens and inequalities.

\section{Objectification and asymmetrical relationships}

So Habermas's argument against enhancement ultimately rests on his account of how the beings created understand the intentions of their creators and what this does to the relationship between them. The beings created will see themselves as objects created for the purposes of another. A parent who engages in selection or modification "approaches the quasi-subjective nature of this embryo in the same perspective as he would approach objective nature." 40 This is reminiscent of Lewis's remark about raw material, and it has an impact on how the created child must ultimately see herself.

[B] eing confronted with the sedim ented intention of a third person in on e's hereditary factors requires the subject concerned to come to terms with this fact. The programm ed person cannot see the program mer's intention, reaching through the genom e, as a conti ngent circumstance restricting her scope of action.

'Contingent' in this context means non-deliberate. Contingent circumstances, such as the genetic constitution of a person created in the usual way, are factors with which one must deal; they are background conditions against which one must make one's life. Such circumstances may pose obstacles, but they do not compel an individual to see herself as something other than free or less than others. An individual can see herself as "the undivided author" of her own life if she must wrestle internally only with contingent circumstances. But if the intentions of another reach through her genome, then the individual sees her freedom as compromised. This explains why Habermas says that genetic determinism is not what is troubling. As he puts it: 
All persons, including those born natu rally, are in one w ay or another dependent on their genetic program . There must be a differ ent reason for dependence on a deliberately fixed genetic program to be relevant for the programmed person. He is principally barred from exchanging roles with his designer. $^{42}$

This means, according to Habermas, that the relationship between the creating parents and the created child is irreversibly asymmetrical. And Habermas portrays this as a bad thing, a moral loss. But why?

Habermas says that the programming intentions of the parents "have the peculiar status of a one-sided and unchallengeable expectation." 43 Through their actions, they have created "an interpersonal relationship for which there is no precedent." Their irreversible choice "jeopardizes a pre-condition for the moral self-understanding of autonomous actors." "44 The actions of the designing parents "lay the grounds for a social relationship in which the usual 'reciprocity between persons of equal birth' is revoked." 45 A fundamental assumption of our moral outlook is (moral) equality. This is undermined by genetic intervention.

...[A]s the designer $m$ akes himself the co-author of the life of another, he intrudes - from the interior, one could say - into the other's consciousness of her own autonom y. The programme d person, being no longer certain about the contingency of the natural $r$ oots of her life hist ory, may feel the lack of a mental precondition for coping with the moral expectation to take, even if only in retrospect, the sole responsibility for her own life. ${ }^{46}$

The parent, the designer, chose or altered the genome of the child. And Habermas seems to hold that this contingency is lost if even one trait of the child is deliberately selected by the parents. As a result, this is a one-sided relationship; it is impossible for the participants to exchange roles.

This identified asymmetry is bad, according to Habermas, because it is incompatible with our commitment to moral equality. If it were the case that modification or selection precluded moral equality, then I would agree that there is something undesirable about giving parents such powers. (Whether this provides adequate grounds for moral or legal prohibition, however, is a separate issue.) But I do not think that this asymmetry is bad in the way that Habermas says. This can be shown in several ways.

The first point to note is that the parent-child relationship (in contexts unrelated to genetic selection) is asymmetrical in multiple ways. Parents bring children into existence and are responsible for raising them; children cannot have this same responsibility for their parents. And even if children do have obligations to care for their elderly parents, ${ }^{47}$ the content of those requirements differs significantly from parental duties to young children. Parents are required to raise their children so that they can flourish and fend for themselves. This requires, in part, giving children the tools they need to develop their own autonomous wishes and find their own places in the world. By contrast, when grown children assume responsibility for the care of their elderly parents, the decisions of the children should be guided at least in part by the beliefs and values that the parents themselves held when they were fully competent. 
The relationship is asymmetrical in other ways. Where parents choose to live and how well parents do economically may greatly influence the options available to their children; the reverse is seldom true. Robert Nozick notes another curious difference. "The accomplishments of parents might perhaps constitute a burden for their children but, in an asymmetry that seems unfair, those [accomplishments] of the children redound to their parents too." ${ }^{48}$ No doubt many other asymmetries could be identified. None of them, however, seems morally problematic.

The second point to note, then, is that asymmetrical relations do not preclude the possibility of moral equality. Many relationships are asymmetrical: those between teacher and student, between physician and patient, between attorney and client. The obligations of the parties in these relationships are fundamentally different, but that does not mean that they are not morally equal in the important sense of that expression. Defenders of Habermas might protest that those who occupy these various roles do so voluntarily. So we can envision the student becoming the teacher, the patient also being a doctor, and the like. But such a reversal is not possible for parent and child. So if the possibility of exchanging roles is a necessary condition of moral equality, as Habermas suggests, ${ }^{49}$ then perhaps his argument against genetic selection can be salvaged. For the genetically designed child can never exchange roles with the designing parent.

The possibility of exchanging roles is not necessary for moral equality, however. Notice that children can never exchange roles with their own parents, regardless of the state of biotechnology. Moral equality means that the fundamental rights that each of us possesses are the same. Habermas himself suggests that the key here is "mutual respect" and "mutual recognition." 50 But such mutuality is consistent with the fact that particular rights and obligations vary with roles. Each of us is, necessarily, a child at some point, and we have the rights and obligations that all children have. Each of us might become a parent, and if we do we have the rights and obligations that all parents have. Moral equality may demand that each of us has a (prima facie) right to pursue the various roles available in society. And it is true that a (partially) designed child is "barred from exchanging roles with his designer." child, however, no matter how he was created, can exchange roles with his parents. Morally asymmetrical relationships are not necessarily a bad thing and they do not preclude mutual recognition and respect.

An argument similar to Habermas's recently has been made by Dena Davis; however, she applies it to a particular type of selection, reproductive cloning. Davis is concerned with what she calls cloning from "duplicative motivations." 52 Some prospective parents may resort to cloning as a response to infertility. Their motivations are said to be "logistical." "53 But those moved by duplicative considerations want their child to have very specific traits. Davis condemns this, appealing to what Joel Feinberg called a child's right to an open future. ${ }^{54}$ Davis writes, "The harm, I think, lies in the radical ways in which cloning for these kinds of duplicative motivations limits the child's right to an open future, because it violates the child's nascent autonomy and narrows the scope of her choices when she grows up." Davis recognises that to suggest that this child's future is severely restricted by her genetic endowment seems to assume the truth of genetic determinism, a view that she rejects. To fill out her argument, Davis appeals to what Hans Jonas called a "right to ignorance." Objecting to reproductive cloning, Jonas says that "the replication of a genotype creates inherently unequal conditions for the phenotypes concerned - and an inequality deadly for the clone." 56

Genomics, Society and Policy, Vol.6, No.3 (2010/11) ISSN: 1746-5354

(C) ESRC Genomics Network. 
Such replication violates the child's right to ignorance, "a right which had lain dormant and hidden for lack of a call for it" until recent biotechnological developments. ${ }^{57}$ But why is a child's right to ignorance violated? Does Jonas think that others will know how the child will turn out because of their knowledge of her genotype? That is not his view. "It is all a matter much more of supposed than real knowledge, of opinion than truth. Note that it does not matter one jot whether the genotype is really, by its own force, a person's fate: it is made his fate by the very assumptions in cloning him, which by their imposition on all concerned become a force themselves." 58

So the real objection of both Jonas and Davis to reproductive cloning is that parents (and others) will treat the child in such a way as to restrict severely her right to an open future. Thomas Murray indicates how this might be applied to enhancement: "When biomedical enhancement is enlisted in the service of fantasies of parental control, all that is most precious and beautiful in the relationship between parent and child is threatened."59 This is clearly neither an argument against cloning nor positive selection of traits as such; for a cloned being could be adopted by those who had no knowledge of her genotype or specific expectations based on such knowledge. If what is wrong is imposing expectations on a child and thereby restricting her options, then that is what the right to an open future prohibits. Unless there is an inevitable connection between such selection and subsequent wrong conduct, genetic selection and cloning remain untouched by the argument.

In concluding this section, I should acknowledge that parents can and sometimes do misuse the power that they have over their children. If parents have a right to engage in genetic selection or modification, they might exercise that power in a way that works to the detriment of the child. But this is true of many powers that parents have had for centuries, powers that are in no way dependent on biotechnology. Parents have an obligation to utilise these powers in ways that promote the well-being of their children. And this brings us to an obvious point. It seems that selection and modification can both be used to avoid horrible diseases, and when such an option is readily available to parents they are at least permitted to use it. (How Habermas deals with genetic manipulation for the purpose of avoiding disease will be discussed in the following section.) Most critics of genetic enhancement agree with this. Yet it seems that many of the arguments against enhancement can also be used to condemn treatment. Habermas himself uses the phrase "right to an unmanipulated genetic heritage," 60 and it seems that selection or modification aimed at avoiding disease is as manipulative as when either of these is directed toward improvement. So we need to consider how the critics whose views we have discussed handle this issue.

\section{Therapy, enhancement, and consent}

Lewis begins his discussion by describing a man afflicted with tuberculosis. Apparently hoping for a cure, Lewis quotes the individual as saying, "Man has Nature whacked." 61 Lewis goes on, "I have chosen this story as my point of departure in order to make it clear that I do not wish to disparage all that is really beneficial in the process described as 'Man's conquest'..."62 No reason is given, however, to explain why this sort of conquest is allowed, while others are impermissible.

Ramsey too approves of therapeutic interventions but not enhancement. Initially his only reason for this seems to be that treatment aims to help a particular patient, while enhancement

Genomics, Society and Policy, Vol.6, No.3 (2010/11) ISSN: 1746-5354

(C) ESRC Genomics Network. 
is directed to "that celebrated nonpatient, the human species." ${ }^{63}$ It is not even clear why Ramsey thinks of this as a relevant reason. One possibility is that when the goal of an intervention is to advance the species rather than to help an individual, then the practice is eugenic. But if that is what Ramsey has in mind, further explanation is needed.

Later, however, Ramsey does provide a different defense of his position. He says that if an intervention that has as its aim "to correct some serious genetic defect" goes awry, that is a "tragedy" but nevertheless justifiable because of its therapeutic goal. But it would be a "miscarriage of justice" if "the mishap resulted from experimenting on the child in a program of positive eugenics for the supposed sake of the species." 64 The argument here seems to say that putting an individual at risk is justifiable if it is for her own benefit, but not justifiable if it is for the benefit of the species. So understood, this may be too weak; for pursuing an enhancement could be viewed as seeking to help the individual created. An altered version of this argument may avoid this difficulty. One might claim that medical practitioners are justified in subjecting a patient to a risk only if they are trying to avoid "some serious genetic defect"; they are not justified in exposing an individual to risk, however, if the goal is to improve an otherwise normal trait. Among other things, this assumes that normality is acceptable (or good enough), and that doing nothing is not a risk. But neither assumption is obvious, and at the very least each requires justification. ${ }^{65}$

Habermas's line of reasoning here is more interesting than that of Ramsey. He acknowledges the he wants "to permit therapeutic genetic interventions (or even selections) in cases of serious genetic disorders." ${ }^{66}$ He also concedes that the distinction between therapy and enhancement is blurry. Goals such as "strengthening the immunosystem or prolonging the lifespan" are positive but "nevertheless consistent with clinical goals." 67 The attitude of the clinician is fundamentally different from that of the enhancer. For the clinician, "there is no need ... to approach the embryo in the objectivating attitude of the technician"; instead, the intervener can "approach the embryo as the second person he will one day be." 68 Talk about approaching the embryo seems rather mysterious, but Habermas tries to demystify the idea by appealing to the notion of consent.

As long as m edical intervention is guide $\mathrm{d}$ by the clinical goal of healing a disease or of $\mathrm{m}$ aking provisions for a healthy life, the person carrying out the treatment may assume that he has the consent of the patient preventively treated. The presumption of informed consent transforms egocentric action into communicative action. ${ }^{6}$

This still seems unclear. Perhaps Habermas agrees, for in his "Postscript" he addresses this point again. He reiterates, "All therapeutic genetic interventions, including prenatal ones, must remain dependent on consent that is at least counterfactually attributed to those possibly affected by them." But when are such attributions of consent warranted? "Attributing such consent can only be justified in cases where there is a certain prognosis of extreme suffering. We can only expect a consensus among otherwise highly divergent value orientations in the face of the challenge to prevent extreme evils rejected by everybody."70

This rationale is troubling for multiple reasons. First, hypothetical consent is still not actual consent; and it is certainly not informed consent. This notion may have moral efficacy in some contexts, but a specific argument is needed to show how it works here. ${ }^{71}$ Second, the imagined consensus is hard to pin down. It seems too obvious to say that many but not all 
would probably agree to a genetic modification that eliminated trait X. But Habermas says that it must be "evils rejected by everybody," and it is hard to be confident that this condition is satisfied in any given case. Just think about the controversies surrounding the issue that has been dubbed "selecting for disability". Third, it seems that we cannot be at all confident that any given individual would not (later) consent to the provision of an enhancement, or at least be happy that he had the trait in question.

Habermas provides an answer to this third point that is revealing. Consider what some have called 'all-purpose goods'. ${ }^{72}$ These are goods that are advantageous for the possessor regardless of his particular values and plans for life. Intelligence and good health are obvious candidates for such a type of good. Habermas dismisses these. "A good memory is often but by no means always a blessing." And again: "The same is true for outstanding intelligence. In many situations it is a predicable advantage. But how will the 'head start' of high intelligence play itself out in a competitive society - for example, in the character formation of the highly talented person?" And again: "Not even the highly general good of bodily health maintains one and the same value within the contexts of different life histories. Parents can't even know whether a mild physical handicap may not prove in the end to be an advantage for their child." 73 The underlying principle, then, is that if parents cannot know that having X (or eliminating Y) would be regarded as an advantage by their particular child, they are not justified in intervening so that their child will have X (or lack Y). At best, only the elimination of horrific diseases will pass this test.

Suppose the X represents a good memory and suppose that the prospective parents opt to modify an embryo so that their child has an excellent memory. If this child subsequently says, "I wish that I did not have such a good memory," that is taken to show that the parents chose wrongly. But now suppose that the parents choose not to modify a given embryo in the same way. And suppose subsequently that this child says, "I wish that I had a better memory. It would make my life so much better." This is not taken to show that the parents chose wrongly. But why? It seems that this puts undue weight on the distinction between acts and omissions. Any intervention that is later rejected by the child is thereby wrong; but any failure to intervene, no matter how deeply regretted (later) by the child, is not wrong. Any possibility of getting it wrong blocks action; but inaction is never portrayed as too risky. This is a form of the status quo bias that seems hard to justify.

The underlying principle is even more extreme than I have described so far. It is not enough to render an intervention permissible that the child subsequently accepts it (or is happy about it). It must be the case that the parents know that the child will give her consent. Habermas is not only aware of this; he embraces it when he says that consent can be assumed only "where there is a certain prognosis of extreme suffering." 74 To understand this position better, let us situate it in the context of surrogate decision making. When a surrogate must make a decision for an adult who was previously competent, it is generally agreed that the patient's own values and wishes, if known, should guide the surrogate's decisions. ${ }^{75}$ But if the patient is not yet competent, has never been competent, or if his previous wishes cannot be known, then a surrogate should follow the best interest principle. ${ }^{76}$ Since children are not yet competent, it would seem that only the best interest principle could guide their surrogates. But Habermas, in effect, denies that the best interests principle alone can justify genetic interventions for children. Instead, such interventions are permitted only if they "prevent extreme evils rejected by everybody." Notice the implications if this standard applies in all cases. Treatments 
initiated based on the results of newborn screening are justified by appealing to the child's best interests; but it is not clear that these interventions always prevent extreme suffering "rejected by everybody". And think of the situation in which an accident victim (whose identity is not known) is unconscious and has suffered internal injuries. If this patient needs surgery and the administration of blood, health care professionals will provide such treatments based on the best interest principle. This seems justified even though a small minority of patients will, after recovery, wish that they had not received blood products because of religious objections. The mere fact that a few people will not subsequently consent to an intervention regarded by most as beneficial does not render that intervention impermissible.

One final point is in order concerning the claim that individuals will subsequently consent to treatment but not to enhancement. Even if this rationale were plausible, it would apply only to genetic modification, not to selection. For in the case of selection, any given embryo is chosen or rejected based on (some of) its genetic traits. If a fertilised egg is chosen, is transferred to a woman, and later comes to term, the resulting person cannot coherently object that she has trait X or lacks trait $\mathrm{Y}$; if these are genetically based traits, they are a core part of the individual. And if a fertilised egg is not chosen, there is no being who subsequently fails to give consent.

\section{Conclusion}

Habermas provides a more interesting and complex argument against certain kinds of genetic interventions than either Lewis or Ramsey. All are opponents, in part, because they believe that the created beings are treated as objects; but Habermas rests his case on what he takes to be the correct way to understand the parent-child relationship. He says, reasonably in my view, that we are committed to a kind of egalitarianism that assigns equal moral status to all persons. He argues that allowing prospective parents to engage in genetic choices gives them a kind of power that creates a deeply asymmetrical relationship between them and their children. And he thinks that this asymmetry undermines the moral equality of parents and children by diminishing the status of the latter, making them mere things. Since the argument is sometimes pitched against genetic manipulation, Habermas recognises that it may appear to preclude not only genetic enhancement, but treatment too. To avoid what he regards as this untoward implication, he argues that treatment does not view the child-to-be as a mere thing because its consent can be assumed. Assuming such consent in the case of enhancing interventions is, however, not warranted. Against this, I argue that permitting enhancement does not create any asymmetries that are morally different from those that have existed for a long time, and so it need not undermine the assumption of moral equality. As for the subsequent consent of the child-to-be, either it is reasonable to think that it would consent to at least some enhancements, or the standard for saying when it would consent is so demanding that nearly all interventions (even many treatments) would fail the test. And all of this assumes that we can make sense of the claim that some future individual would consent to things that have been done to it, a proposition which I doubt.

There may be other arguments that demonstrate that prospective parents should not be permitted to use interventions that will deliberately impact the genetic makeup of their children. But the arguments examined here - even with their long history - are not sufficient to show this. 


\section{Acknowledgments}

Earlier versions of this paper were presented at the Conference on Philosophical Societies (December 2010) and at Davidson College (April 2011). I thank members of those audiences for comments and suggestions, and I also thank my colleagues who are part of an informal ethics discussion group for their help. Two readers for this journal provided many useful comments. I especially benefited from the suggestions of Heather Gert and from the detailed comments of Norvin Richards.

\footnotetext{
${ }^{1}$ University of North Carolina at Greensboro. tcmcconn@uncg.edu

2 J. Harris. 2007. Enhancing Evolution: The Ethical Case for Making Better People. Princeton: Princeton University Press: 9.

${ }^{3}$ S. Wilkinson. 2010. Choosing Tomorrow's Children: The Ethics of Selective Reproduction. New York: Oxford University Press: 186-187. See also, P. Singer. 2010. Prenatal Choice and Human Improvement. In Human Enhancement. J. Salvulescu and N. Bostrom, eds. New York: Oxford University Press: 278.

${ }^{4}$ Among the proponents of this objection are F. Fukuyama. 2002. Our Posthuman Future: Consequences of the Biotechnological Revolution. New York: Picador Books; and President's Council on Bioethics. 2003. Beyond Therapy: Biotechnology and the Pursuit of Happiness. New York: Regan Books. For criticisms of these arguments, see T. McConnell. Genetic Enhancement, Human Nature, and Rights. The Journal of Medicine and Philosophy 2010; 35: 415-428.

${ }^{5}$ See M. Sandel. 2007. The Case Against Perfection: Ethics in the Age of Genetic Engineering. Cambridge, MA: Harvard University Press. For criticisms of Sandel's arguments, see T. McConnell. Genetic Enhancement and Moral Attitudes Toward the Given. Journal of Applied Philosophy 2011; 28: forthcoming.

${ }^{6}$ P. Ramsey. 1970. Fabricated Man: The Ethics of Genetic Control. New Haven: Yale University Press.

${ }^{7}$ Wilkinson, op. cit. note 3, pp. 187-190.

${ }^{8}$ Ibid, p. 190

${ }^{9}$ C.S. Lewis. 2001/1944. The Abolition of Man. New York: HarperCollins: 53.

${ }^{10}$ Ibid, pp. 54 and 55.

${ }^{11}$ Ibid, p. 72.

12 Ibid, pp. 62 and 63.

${ }^{13}$ Ramsey, op. cit. note 5, p. 104.

${ }^{14}$ Ibid, pp. 107 and 133.

${ }^{15}$ Ibid, p. 151.

${ }^{16}$ Ibid, p. 135.

${ }^{17}$ Ibid, pp. 150-151.

${ }^{18}$ Ibid, p. 151.

${ }^{19}$ J. Habermas. 2003. The Future of Human Nature. Cambridge: Polity Press: 79.

${ }^{20}$ Ibid, pp. 46 and 47.

${ }^{21}$ Ibid, p. 77.

${ }^{22}$ Ibid, p. 75.

${ }^{23}$ Ibid, p. 58.

${ }^{24}$ Ibid, p. 60.

${ }^{25}$ Ibid, p. 57.

${ }^{26}$ Ibid, p. 59.

${ }^{27}$ Ibid, p. 87.

${ }^{28}$ Ibid, p. 53.

${ }^{29}$ Ibid, p. 53.

${ }^{30}$ Ibid, p. 53.

${ }^{31}$ Ibid, p. 83.

${ }^{32}$ Ibid, p. 63.

${ }^{33}$ Ibid, pp. 49-50 and pp. 61-62.

${ }^{34}$ Ibid, p. 51 and p. 62.
} 
${ }^{35}$ See J. Radcliffe Richards. 2000. Human Nature After Darwin. New York: Routledge: 121.

${ }^{36}$ J. S. Mill. 1989/1873. Autobiography. New York: Penguin Books: 126. Some say that Mill's period of depression resulted from viewing himself as nothing but a paternal project. Mill himself, however, denied this. He said that his crisis was due to a failure to embrace fully the end of promoting human happiness. As a result of the crisis, he changed how he approached ends and some of his views about human nature. See Chapter V, especially p. 113 and pp. 117-118.

${ }^{37}$ Habermas, op. cit. note 18, p. 62.

${ }^{38}$ Ibid p. 66. See also, ibid, note 54, p. 124.

${ }^{39}$ Ibid, p. 61 .

${ }^{40}$ Ibid, p. 50.

${ }^{41}$ Ibid, p. 60

${ }^{42}$ Ibid, pp. 64-65.

${ }^{43}$ Ibid, p. 51.

${ }^{44}$ Ibid, p. 63

${ }^{45}$ Ibid, p. 64

${ }^{46}$ Ibid, pp. 81-82.

${ }^{47}$ On this topic, see T. McConnell. 1993. Gratitude. Philadelphia: Temple University Press. Chapter VII.

${ }^{48}$ R. Nozick. 1989. The Examined Life. New York: Simon \& Schuster: 29.

${ }^{49}$ Habermas, op. cit. note 18, p. 65.

${ }^{50}$ Ibid, pp. 33 and 65.

51 Ibid, p. 65

52 D. Davis. 2010. Genetic Dilemmas. New York: Oxford University Press, second edition: 160-161.

${ }^{53}$ Ibid, p. 158.

${ }^{54}$ J. Feinberg. 1992. The Child's Right to an Open Future. In Freedom and Fulfillment. Princeton, NJ: Princeton University Press: 76-97.

${ }^{55}$ Davis, op. cit. note 50, p. 163.

${ }^{56}$ H. Jonas. 1974. Philosophical Essays: From Ancient Creed to Technological Man. Englewood Cliffs, NJ: Prentice-Hall: 160.

${ }^{57}$ Ibid, p. 161.

${ }^{58}$ Ibid, p. 161.

${ }^{59}$ T. Murray. 2007. Enhancement. In The Oxford Handbook of Bioethics. B. Steinbock, ed. New York: Oxford University Press.

${ }^{60}$ Habermas, op. cit. note 18 , p. 22 and p. 27

${ }^{61}$ Lewis, op. cit. note 8, p. 53.

${ }^{62}$ Ibid, pp. 53-54.

${ }^{63}$ Ramsey,op. cit. note 5, p. 112.

${ }^{64}$ Ibid, pp. 115-116.

${ }^{65}$ See J. Harris. 2010. Enhancements are a Moral Obligation. In Human Enhancement, op. cit. note 2, pp. $147-$ 151, commenting on the views of N. Daniels. 2010. Can Anyone Really Be Talking About Ethically Modifying Human Nature? In Human Enhancement, op.cit. note 2, pp. 25-42.

${ }^{66}$ Habermas, op. cit. note 18, p. 90.

${ }^{67}$ Ibid, p. 51 . See also, pp. 19 and 21.

${ }^{68}$ Ibid, p. 52 and p. 43 .

${ }^{69}$ Ibid, p. 52.

${ }^{70}$ Ibid, p. 91 .

${ }^{71}$ See R. Dworkin. 1977. Taking Rights Seriously.Cambridge, MA: Harvard University Press. Chapter 6. For an extensive discussion of the issue of hypothetical consent in the context of medical ethics, see A. Kuflik. 2010.

Hypothetical Consent. In The Ethics of Consent. F. Miller and A. Wertheimer, eds. New York: Oxford University Press: 131-161.

${ }^{72}$ See A. Buchanan et al. 2000. From Chance to Choice: Genetics and Justice. New York: Cambridge University Press: 167-170.

${ }^{73}$ Habermas,op. cit. note 18 , pp. 85-86.

${ }^{74}$ Ibid, p. 91.

75 See A. Buchanan and D. Brock. 1989. Deciding for Others: The Ethics of Surrogate Decision Making. Cambridge: Cambridge University Press: 98-122 (discussing the advance directive principle and the substituted judgment principle).

${ }^{76}$ Ibid, pp. 122-134. 